\title{
THE IMPORTANCE OF FINANCIAL INSTITUTIONS FOR THE DEVELOPMENT OF THE BRAZILIAN AMAZON: AN APPLICATION OF THE SOCIAL ACCOUNTING MATRIX
}

\author{
LA IMPORTANCIA DE LAS INSTITUCIONES FINANCIERAS PARA \\ EL DESARROLLO DE LA AMAZONIA BRASILEÑA: UNA APLICACION \\ DE LA MATRIZ DE CONTABILIDAD SOCIAL
}

\section{ANDRE CUTRIM CARVALHO*}

Federal University of Pará

\section{DAVID FERREIRA CARVALHO**}

Federal University of Pará

\begin{abstract}
The fundamental purpose of this article is intended to measure the economic impacts that the regional financial institutions are providing along the chain of values of the productive activities located in the Brazilian Amazon and their impacts on economic activities through the Social Accounting Matrix. The main conclusion is that to break the status quo in the region, it is necessary to set a national regional development policy that favors the formation of vertically integrated production chains and a trade policy that encourages the export of most products value-added so that the benefits arising can be internalized in the Brazilian Amazon in the form of income and employment.
\end{abstract}

Keywords: Financial institutions, Brazilian Amazon, Social Accounting Matrix.

JEL Classification: $R 00, R 11, R 15$.

* PhD Economics Professor, Faculty of Economics, Federal University of Pará, Belém, Pará, Brasil. E-mail: andrecc83@gmail.com

** PhD Economics Professor, Faculty of Economics, Federal University of Pará, Belém, Pará, Brasil. E-mail: david.fcarvalho@yahoo.com.br 


\begin{abstract}
Resumen
El propósito fundamental de este artículo es pretender medir el impacto económico que las instituciones financieras regionales están proporcionando a lo largo de la cadena de valor de las actividades productivas ubicadas en la Amazonia brasileña y su impacto en las actividades económicas mediante la Matriz de Contabilidad Social. La principal conclusión es que para romper el statu quo en la región, es necesario establecer una política nacional de desarrollo regional que favorezca la formación de cadenas productivas integradas verticalmente y una política comercial que fomente la exportación de la mayoría de productos de valor agregado para que los beneficios derivados puedan ser internalizados en la Amazonia brasileña en forma de ingresos y empleo.
\end{abstract}

Palabras clave: Instituciones financieras, Amazonia brasileña, Matriz de Contabilidad Social.

Clasificación JEL: R00, R11, R15.

\title{
1. INTRODUCTION
}

In Brazil, the discussion on the social repercussions generated by the deepening of the regional economic differences, in the latest years, is restricted to convergence studies about the federated units' per capita incomes, on polarization reversion and, more recently, about the possibility of local development through the organization of productive chains and, the so called, local productive arrangements.

In this direction, the studies that deal with the question of regional development's financing are relatively scarce in Brazil, remember Amado (1999). The debate on the regional question always had as main focus the regional disparities associated to the asymmetries of the product's real variables, the income and the employment, when the performance of periphery regions (Amazon and Northeast) is compared to the economic center (Southeastern). For Cardim de Carvalho et al. (2001), "the interference of the monetary and financial variables, in the regional question's quarrel, was duly considered just a few times".

However, the articles of Dow (1992) and Chick (1994) came to motivate the theoretical debate about the importance of the currency and the banking system for the regional development. Amado (1999), for instance, admits that the scarcity of financial analysis in the scope of the regional economy is partially due to the adoption of an inadequate theoretical financing reference to approach the financial dynamics and its impacts on the regional production apparatus. The following reasons for such behavior can be identified:

I) The neutral function of the currency as mere way of exchanging goods; 
II) The neutral function of the financial sector as simple financial intermediary between superavits agents (savers) e deficits agents (investors);

III) The function of the Central Bank as mere sanctioned of the currency in course forced to passively accommodate the real aggregate demand.

Thus, a question must guide the discussion of the present article: which should be the most appropriated financing standard of the regional development to overcome the limited capacity of financing strategic projects from the periphery regions of Brazil? which would be the most appropriated model? A regional financial system part of the national financial system, formed by a network of regional bank agencies; or a national financial system model with a wide network of agencies distributed throughout the national territory?

For the conventional theory of the borrowed funds, the formation of a national financial system can create convergent trajectories of economic development between the developed dynamic center and the delayed dependent periphery. This conception is based on the primitive period of the financial system when, supposedly, the "financial" flows equal the savings (deposits) to the investment (loans), as the economists of the orthodox side think.

However, nothing assures that this can really happen, because if the financing logic of the investments is of the market, such national financial model with limited level of regional integration, besides the absence of positive externalities and public development banks, could deepen even more the regional inequalities due to, especially, the advanced stage in which the current financial Brazilian system is ${ }^{1}$.

Similarly it could be argued that an integrated financial model could be much more advantageous than a regional financial model - mainly due to the efficiency of the organizational and management structures, the positive externalities from technological, financial and operational innovations and the earnings from scale and scope economies - as it could provide, from the financial center where the headquarters of banks operating in the peripheral economy are located, a greater ability to finance investment for productive activities from peripheral regions.

However, although this possibility exists, the necessity of consolidating a national pattern of regional financial development, in developing economies, cannot discard the importance of the planning and regulating actions of the State, particularly in regard to the support needed to overcome the delay of the peripheral economies.

According Amado (1999), in such circumstances, the emptying of financial flows could harm the constitution of the "revolving fund" to finance by Keynes, as there would be a trend of declining bank deposits levels in agencies of the underdeveloped areas of the periphery. In the case of Brazil, the institutional definition of the national standard of funding for regional development must consider, besides the current

\footnotetext{
In the fifth stage of the banking system's historical evolution, besides the consolidation of the bank deposits generators of reserves and credit, the presence of the bank currency as one of payment, the development of loans between banks in the interbank market and the central bank's presence admitting the role of the lender of last instance, the banks start to manage the negotiation of debts. See Chick (1994).
} 
advanced stage of public and private financial institutions historical development, the republic entities' interests and its ways of governability and governance.

This article is organized into five sections, including this introductory section, as follows: the second section presents the methodological aspects that will be used for the development of this Article; the third section discusses financial institutions and its economic impacts in the Brazilian Amazon; the fourth section presents an analysis of the results of the implementation of the Social Accounting Matrix; finally, have the final considerations presented in the sixth and final section of the work.

\section{METHODOLOGY: RESEARCH METHOD}

The methodological specification is a mandatory part of academic research to adopt the scientific method; however, we must distinguish the method of approach of mentioned research methods. The method of approach with regard to the philosophical affiliation and the level of abstraction of the phenomenon studied, as research methods or research procedures consist of concrete steps of research and use of appropriate research techniques.

In the social sciences in general, it must be a methodological constraint: that is the need for confrontation of thought reality, abstracted from concrete, with empirical reality, that is, one that is perceived by our senses. In turn, the practical knowledge is subject to the need for immediate connection with reality to which they refer. Therefore, the theoretical research, unlike the empirical research - while the research method based on primary data from field surveys or even collection of secondary data - the research method has more to do with the method of exposition of ideas: if deductive or inductive.

In the present case, the approach adopted follows the hypothetical-deductive method in that it combines the deductive method, from the theoretical framework built with the inductive (empirical) method in that it uses the basic matrix data to test the central hypothesis of the economic impacts that the chain of non-metallic mineral sector in the economy because of the North Region of Brazil.

\section{FINANCIAL INSTITUTIONS AND ITS ECONOMIC IMPACTS IN THE BRAZILIAN AMAZON}

In the Brazilian case and elsewhere in Latin America, experience has shown that, if there is no creation of public financial institutions of pro-economic development, to work within a long term view of strategic planning, the possibilities of a national underdeveloped economy to solve the problems of inter-sectoral or inter-regional transfer of funds to delayed sectors or regions through the spontaneous development by the exclusive way of the financial market will become very scarce. This is not to deny the importance that has had the capital and credit markets as the diversification of resources, including preventing waste of personal savings. 
The theoretical construction of Gurley and Shaw (1960) innovated on the genesis of financial market's structure and its impact on the operation of the economic system. Accordingly, Fray (1961):

They had the merit to associate the problem of the economic development to the development of the financial system; to watch the importance of the creditor's risk on the structure of the financial market; and to transfer attention from interest rates to the quantitative and qualitative dimension of the demand and search for capital.

However, author as Gurley and Shaw (1960); Hirschman (1961) associate the financial development only to the balanced economic development, not to unbalanced economic development. Among the balanced economic development of concepts stands out the one in which it is supposed an investment policy capable of presenting a balanced sectoral growth of various industries simultaneously in a region in order to capture the external economies, as highlighted by Scitovsky (1969).

Nevertheless, changes in the production and distribution structure, as well as technological innovation, induced by the dynamics of the economic system, have repercussions on the structure of the financial market, especially as the private and public sectors, while important sectors for development in terms of income generation and employment, play important roles in the financial market, especially when the financing of investments is seen as the result of the confrontation of supply and demand in the financial market. In addition, register the dynamics of economic and financial systems is subject to uncertainty that produces certain changes in the structure of the financial market.

The organization of a modern financial market, comprising the credit and capital markets, enables the domestic savings to be risen to a certain level of the gross domestic product of an economy. Gurley and Shaw (1960) note that an efficient financial market supposedly allows scarce saving is applied in an excellent way, among the various areas of alternative investment, so that the economy's pace of growth is made at a higher rate than that where it would be an inefficient financial organization. Indeed, an incomplete national financial system is an obstacle to sustainable development. This brings into focus the effects of the financial market structure on the dynamics of regional economic system.

In the neoclassic models, the financial market is basically summarized to the market of borrowed funds and, thus, is defined as the locus where it is found the search and the demand of payment ways needed to cross the past time period between the decisions of agent's expenses of productive and consumption investment, and the formation of the monetary incomes of the families, remember Fray (1961).

In this view, on the supply side, the main funding sources of loanable funds are: current savings generated in a given period; divestment; dishoarding liquid; and net loans of additional banks. In contrast, the search for "funds" available can be composed of: funds for spending in the production of fixed capital investments or working capital; funds for hoarding; and funds for the expenditure of consumption, individual or collective, as well as current income. 
In this neoclassical definition of a financial market, the above classification is shown somewhat arbitrary, since the self-financing problems and the importance of non-bank financial institutions are ignored, apart from the fact that the design of loanable funds theory proves to be a static approach ex post. Therefore, such a situation is a static concept because in dynamic terms would be difficult to separate the demand and the overall supply of components, any one of them for a given type of individual.

Moreover, it is an ex post concept because it is evident the attempt to specify in detail the supply and demand equilibrium position of loanable funds theory, in terms of real variables, reflecting the market clearing, i.e. equality between saving and business investment and equality of the supply of bank credit and the demand for loans in household consumption. Fray (1961) says:

Starting from a classification of the demand for credit by customers, also with little bit of arbitrariness, defines the financial market in other way, in dynamic terms, considering all active individuals who make decisions on the financial market: 1) companies; 2) families; banks and credit institutions; 3) other financial institutions; and public banks. These categories may take a mixed financial position of applicants and suppliers of funds in the financial market, including involving the self-financing.

The structure of the financial market therefore should be characterized in their quantitative and qualitative aspects. The first group has the number of active individuals in the market, the dimensions of the activities they perform, and the number and volume of securities "primary" and "secondary". In the second group, figure types of financial institutions (monetary financial institutions and non-monetary), bond and how the stock market reacts to economic activities. In the third group, finally, are the other private financial institutions and banks and public funding agencies

Fray (1961), when considering the accumulation of capital in the form of investments that allows technical progress act, in the sense of generating economies of scale and increasing production capacity capable of causing profound changes in the productive structure, contributes to the acceptance of a standard unbalanced development as advocated by Hirschman. The unbalanced development releases, in turn, driving forces that trigger a sequence of inductive imbalances in economic activities of the various supply chains of an economy.

In turn, the configuration of a development pattern of financial savings also evolves over time. In a first step of the development of a financial system, families and companies seek financial intermediaries only to raise their capital-money in the financial movement sphere. In the second step, it is the financial intermediaries that seek credit demanding customers and loans are given based on criteria of profitability, liquidity and applications' risk and not only by their social or developmental projects. The access to resources from financial institutions is determined by the guarantees that the borrower can provide to the creditor, which means that, in general, actors who are already established in areas of higher profitability and can offer "safer" applications are favored. 
In a developing economy, such as Brazilian, a significant parcel of many commercial banks and multiples' resource is directed to financing the families' capital goods and the working capital of enterprises, and less to the financing of investments in new activities or key strategic sectors for development. In the specific case of small companies, the solution in a greater or lesser extent has been the establishment of a specific financial intermediation that is disconnected from the formal financial market.

Alternatively, for strategic investments in productive sectors and economic and social infrastructure, it has been directed to public funds or public-private partnerships. The elements highlighted here will anchor the empirical analysis of the indicators from the Social Accounting Matrix.

\subsection{Methodology for application of the Social Accounting Matrix}

The construction of the Social Accounting Matrix is made from the Input-Output Matrix developed by Leontief $(1966 ; 1970)$. In this work, however, only take place applying the model from the Social Accounting Matrix built by Santana (2004). In general lines, the Input-Output Matrix is an analytical tool which has been widely used in the inter-sectorial analysis. The economic theory tries to explain the transactions and economic relations existing in a market economy in terms of the cause and effect interactions between endogenous and exogenous variables.

In classical models, the trajectories of transactions of intermediate goods between sectors occur between two variables, but the individual economic transactions are too numerous and complex to be described in all its particulars, but it is possible to reduce them to a number of variables and ordering, classifying and adding them into groups. This is the methodology used by the input-output analysis to favor the domain of economic theory on the empirical facts with which the theory is concerned with every real situation.

To do this, we must understand that economic transactions are grouped into sectors of production, distribution, transport and consumption that are arranged in a double-entry matrix containing horizontal lines and vertical columns. The values of horizontal rows in the matrix show the distribution of the sales of production for each sector, according to the destination, among all sectors of the economy.

The values of the vertical columns of the matrix show the distribution of purchases of inputs needed in each sector, according to the source, among all sectors of economy. The element that appears in a cell, where the $i$-th row and the $i$-th column represents the value of production of sector $i$ that is absorbed as input by sector $j$. In any cell, as the value in a row is the same value of a column, the production of each sector is also input of another, hence the input-output description.

However, despite the recognition of the importance of the input-output model, the results obtained from the application of the original models by Leontief input-output, or input-output model modified by Miyazawa (1966), may underestimate the impacts of activities that comprise the economy of the Brazilian Amazon. Indeed, the results of the Input-Output Matrix have shown relevant when it comes to estimate the multiplier effects of the product, income and employment in an economy. 
Authors as Bernat and Johnson (1991) note that when it comes to measuring the productive effects back and forth of the activities, the Input-Output Matrix not directly incorporate the economic flows models that depart from productive activities for the production and these factors for institutions (households and government), and neither include in full the feedback of relations arising in final demand for goods and services.

To avoid this problem, new matrices generation was constructed by Stone (1985) "more disaggregated and consistent with the macroeconomic analysis of a country or region, in order to allow an appropriate structure to the circular flow of any market economy at national or regional contexts".

These are the reasons that justify the use of Social Accounting Matrix to analyze not only the global multiplier effects of the sector, but also the chaining effects of backward and forward Financial Institutions services on the production structure of the Brazilian Amazon.

\subsection{Data sources}

The database to measure the effects of the product multipliers, income and employment, as well as the effects of chaining (linkages) back and forward generated by financial institutions in the Amazon is the Input-Output Matrix of Brazilian Amazon 1999, which was prepared by Guilhoto and Sesso (2005) as a product of the agreement between the Bank of the Amazon (in Brazil called Banco da Amazônia or BASA) and the Institute for Applied Economic Research (in Brazil called Instituto de Pesquisa Econômica Aplicada or IPEA). The used methodology took as reference the new system of national accounts that has been used in Brazil since 1990.

The close connection of chain effects concept in the production process with Social Accounting Matrix is known. However, the concept chain effects, which is essentially a dynamic concept, can be used in a very mechanical way when it interprets the indicators derived from a Social Accounting Matrix without the appropriate restriction, as this is an analysis of input-and output-and, therefore, from synchronous nature.

It is known, consequently, that this is a problem that has hampered the understanding in cross-section or panel analysis, of the extension of dynamic effects in the production chain. The technical-economic forces that facilitate the achievement of the first steps can block the occurrence of the following, making a somewhat extended deployment of the chain effects due to the observed fact to "rely more than usually on public policy in the new process of industrialization", as Hirschman (1961).

\subsection{Hypotheses for the model Social Accounting Matrix}

The accounting system recorded by the double entry method, applied in the construction of Input-Output Matrix, allows the Input-Output Matrix reveals the economic structure of a regional economy from trade flows linking every branch and industry in a particular industry all others. Nevertheless, both the Input-Output Matrix as the Social Accounting Matrix is subject to some general assumptions and other specifics described below: 
I) The hypothesis that the technical coefficients of these matrices are fixed. This means to assume that the technical coefficients do not change in the short term and therefore, there is no substitution of production factors when their relative prices change;

II) The hypothesis of the economy sectors aggregation. This implies that there may be errors on aggregation when the industries of a productive sector are combined. To avoid this problem, it is admitted that enterprises located in an industry produce the same kind of product and that the industries located in the same sector are homogeneous and different from the other industry sectors. This problem is mitigated as the economic structure can be presented in a more disaggregated way, with a larger number of economic activities;

III) The hypothesis of constant returns to scale to all sectors of the economy in general. This means that if the inputs vary in the same proportion, $k$, the production varies exactly alike, in the same proportion.

Beyond these basic hypotheses, the Social Accounting Matrix presents two others that are needed so a regional economy structure is appropriate. One is that the economy operates with idle capacity. This implies that an unexpected demand increase can be answered, at the same cost levels, by increasing the production scale.

Another hypothesis, a Keynesian, is that the market for goods and services are set via quantity. It means that the market disproportions for goods and services are revealed by an involuntary stock accumulation or not accumulation. Finally, there is the neo-keynesian hypothesis of institutional price rigidities due to menu costs, the externalities and information asymmetries. "As a result, the prices of goods of this regional economy remain fixed, at least in the short term", remember Mankiw (1992).

Based on the hypotheses set, the Social Accounting Matrix will be used to capture the effect on chain back and forth, as well as the effects of exogenous injections, by product multipliers of income and employment to the Amazon Brazilian economy.

\subsection{Model structure of the Social Accounting Matrix}

A Social Accounting Matrix is structured using as a base the Input-Output Matrix. In fact, as noted by Pyatt and Round (1979), the Social Accounting Matrix is structured linking to demand matrix for intermediate goods (inputs) to demand matrix for final goods representative of the private and public consumption, private and public investment and exports and imports and the corresponding payments to the factors production (value added). Similarly to the Input-Output Matrix, the structure of Social Accounting Matrix is represented by a general matrix formed by a set of double input cells. The representative of a regional economy Social Accounting Matrix, as well as technological matrix, is the matrix of regional accounts separated by institutions or economic agents.

The Social Accounting Matrix is a square matrix in which the sum of lines and the sum of the columns must be equal. Analyzing The Social Accounting Matrix, we have the rows and columns represent, respectively, the revenue and expenditure of economic agents and their values are accounted for in accordance with the method of double entry. 
Therefore, Social Accounting Matrix is constructed by a square table in which each cell $(i, j)$ defines a particular transaction or a transfer within the economy. Thus, the lines indicate the destination of the flows of accounts and columns indicate the origin of flows of the same accounts, in which case an input a value is revenue (sales) sector $i$ arising from the payment (purchases) made by the sector $j$; or alternatively spending sector $j$ (purchases) paid to the sector $i$ (sales).

Table 1, for example, presents a social accounting matrix model compatible with a general equilibrium model of a given regional economy. In this square matrix representative of the Social Accounting Matrix, the values of each row and column is gathered in the same cell, although they represent separate accounts, define the method of double entry that revenue expenditures are equal. For purposes of simplification, it shows the circular flow diagram (monetary and real) variables. In the basic structure have the following accounts endogenous and exogenous.

A) Endogenous accounts:

(1) Production activities.

(2) Institutions.

(3) Value Added.
B) Exogenous accounts:

(4) Liquid Tax (gross taxes minus subsidies and transfers).

(5) Rest of the World (exports, net income sent imports).

TABLE 1

BASIC STRUCTURE OF THE SOCIAL ACCOUNTING MATRIX

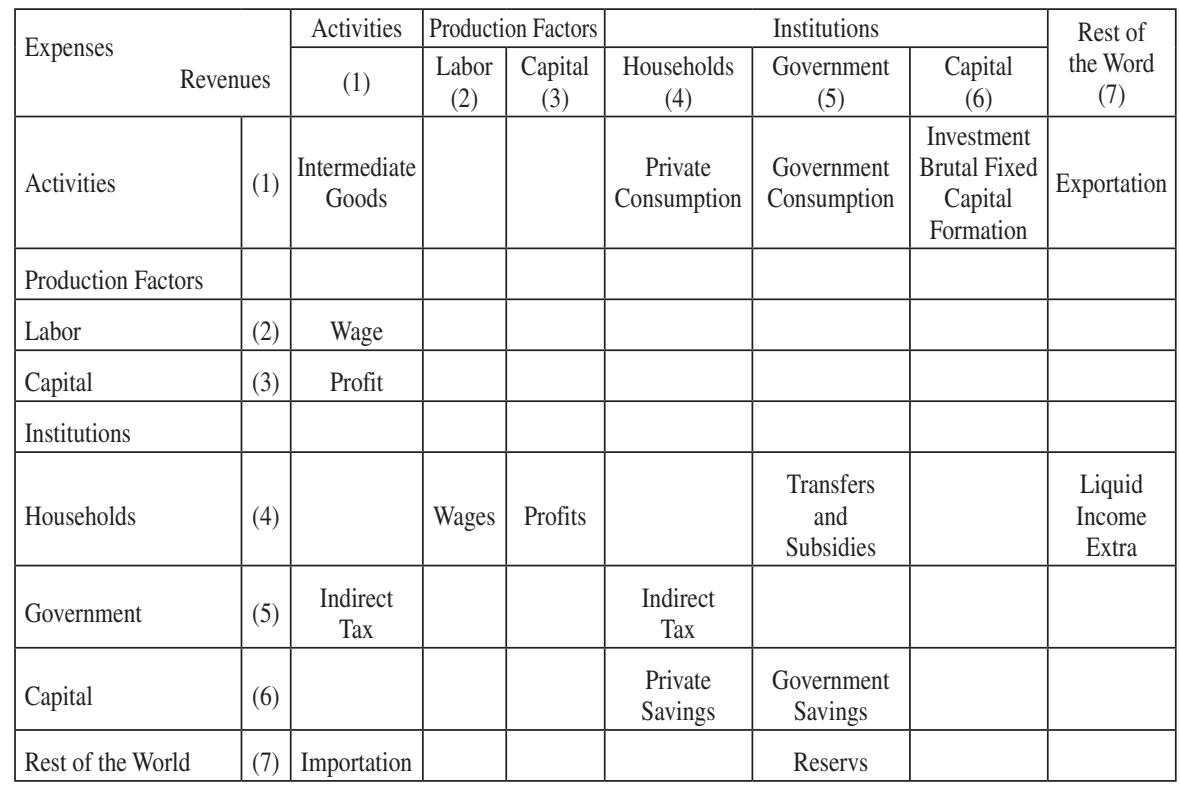

Source: Made by the authors. 
The Social Accounting Matrix comprises three different streams:

(I) Of productive activities, which correspond to the market transactions of goods and services, generating flows of nominal payments and in return the actual flows of goods and services carried out between economic agents;

(II) Of the institution that encompasses all consumers spending made by families and governments and investment expenses incurred by the companies (Brutal Fixed Capital Formation);

(III) Of the added values which involve transactions in the production factor market, corresponding to monetary remuneration of these factors (wages and profits) as real consideration for the services rendered by the same factors (labor and capital); and

(IV) The net tax is the gross total taxes less transfers and subsidies granted by the government;

(V) The rest of the world that matches the flow of exports, imports and liquid income sent.

Suppose be given an exogenous stimulus to productive activities, they respond to such stimulus generating the income corresponding to the remuneration of production factors (labor and capital) that constitutes the value added (in the form of wages and profits); that income generated, in turn, to be passed on to social institutions, is spent on consumer goods by households and estate investments by governments and companies, finished goods produced by these productive activities, then proceed to close the circular flow.

Therefore, it can be said that the circular flow of a regional economy works as follows: stimulating productive activity generates added value that determines the distribution of income of the institutions that income that defines the structure of spending on goods and services that stimulate the back productive activities and so on.

In fact, it is the theoretical basis Keynesian and extensions that support the Social Accounting Matrix model as the dynamics of this model has reference to the principle of aggregate demand. Therefore, it can be said that the Keynesian model based on Social Accounting Matrix has a strong adherence to the dynamics of regional development, as it is guided in stimulating the structuring and development of productive chains whose determination depends on effective demand.

\subsection{The algebraic model of the Social Accounting Matrix}

The Social Accounting Matrix can be presented in a model consisting of algebraic equations, expressed in matrix form, involving all elements of the model. In the terms, the Social Accounting Matrix of the regional economy may be so specified as: 


$$
\begin{gathered}
X_{a}=t_{a} X_{a}+t_{c} R+Y_{a} \\
X_{v}=t_{v} X_{a} \\
X_{i}=t_{r} X_{v} \\
E=t_{e} X_{e}+t_{i} X_{v}
\end{gathered}
$$

Or better:

$$
\left[\begin{array}{ccc}
I-t_{a} & -t_{c} & 0 \\
0 & I & -t_{r} \\
-t_{v} & 0 & I
\end{array}\right] \cdot\left[\begin{array}{c}
X_{a} \\
X_{i} \\
X_{v}
\end{array}\right]=\left[\begin{array}{c}
Y_{a} \\
Y_{i} \\
Y_{v}
\end{array}\right]
$$

The method to solve this model of Social Accounting Matrix is the same used for the Input-Output Matrix and the basic equation representing the final result is given by:

$$
X=(I-A)^{-1} Y=M_{g} Y
$$

where:

$X_{a}=\quad$ is the product vector of productive activities;

$X_{i}=\quad$ is the vector of institutional income;

$X_{v}=\quad$ is the remuneration production factors' vector;

$(I-A)^{-1}=$ is the matrix of global impacts;

$I=\quad$ is the identity matrix;

$A=\quad$ is the technologic matrix;

$Y_{a}=\quad$ is the vector of exogenous income of productive activities;

$Y_{i}=\quad$ is the vector of exogenous institutional income;

$Y_{v}=\quad$ is the vector of value added exogenous.

\subsection{Decomposition of multipliers of the Social Accounting Matrix}

The partitioned Social Accounting Matrix, containing only the endogenous accounts and indicating the average propensity to spend, is structured as a $A$ matrix with size $(n+m+p, n+m+p)$ obtained from the division between the sector values contained in each column by the corresponding value of total expenditure, such that:

$$
A\left[\begin{array}{c}
Y_{a} \\
Y_{i} \\
Y_{v}
\end{array}\right]=\left[\begin{array}{c}
X_{a} \\
X_{i} \\
X_{v}
\end{array}\right] ; \quad A=\left[\begin{array}{ccc}
t_{a} & t_{c} & 0 \\
0 & t_{i} & t_{r} \\
t_{v} & 0 & 0
\end{array}\right]
$$


In this partitioned matrix of the Social Accounting Matrix, we have:

$t_{a}=$ matrix of input-output coefficients with dimension $(n, n) ;$

$t_{c}=$ matrix of dimensions costs coefficients $(n, m)$; ;

$t_{r}=$ matrix of institutional dimension transfer coefficients $(m, p) ;$

$t_{v}=$ matrix of added dimension value coefficients $(p, n)$;

$m=$ in the number of endogenous institutions;

$n=$ is the number of productive activities;

$p=$ is the categories number of added value.

The derivation of the partitioned matrix has as starting point the basic matrix of Leontief:

$$
X=A X+Y
$$

Or:

$$
\begin{gathered}
(I-A) X=Y \\
X=(I-A)^{-1} Y=M_{g} Y \\
X=M_{g} Y
\end{gathered}
$$

The above expression represents the sector income of the endogenous activities as a result of injections in $X$ multiplied by the matrix of the global effects. The $A$ matrix above, can be partitioned into two matrices, represented by $B$ and $C$, so that: $A=B+C$.

The matrices $B$ and $C$ can be written as follows:

$$
B=\left[\begin{array}{ccc}
t_{a} & 0 & 0 \\
0 & t_{i} & 0 \\
0 & 0 & 0
\end{array}\right] ; \quad C=\left[\begin{array}{ccc}
0 & t_{c} & 0 \\
0 & 0 & t_{r} \\
t_{v} & 0 & 0
\end{array}\right]
$$

The matrices $B$ and $C$ are derived from the matrix or the matrix of average propensity to spend or matrix of technical coefficients. Based on this partition, the basic equation of Leontief can be modified as follows:

$$
\begin{gathered}
X=A X+Y \\
X=(A+B-B) X+Y \\
X=(A-B) X+B X+Y \\
X-B X=(A-B) X+Y \\
(I-B) X=(A-B) X+Y \\
X=(I-B)^{-1}(A-B) X+(I-B)^{-1} Y
\end{gathered}
$$


Making:

$$
D=(I-B)^{-1}(A-B)=M_{a i} C
$$

And replacing in (10), we have:

$$
X=D X+(I-B)^{-1} Y
$$

This is the first interactive movement of the matrix process. Multiplying the equation (6) by $D$, we have:

$$
D X=D^{2} X+(I-B)^{-1} D Y
$$

Replacing the equation (7) in equation (6), we have:

$$
\begin{aligned}
& X=D^{2} X+(I-B)^{-1} D Y+(I-B)^{-1} Y \\
& X=D^{2} X+(I-B)^{-1} Y+(I-B)^{-1} D Y
\end{aligned}
$$

Putting in evidence the common factors in $Y$ function, we have:

$$
X=D^{2} X+(I+D)(I-B)^{-1} Y
$$

This is the second movement of the interactive matrix process. Multiplying the equation (7) by $D^{2}$ and replacing (8) in (7) and then isolating the value of $Y$, we have:

$$
X=\left(I-D^{3}\right)^{-1}\left(I+D+D^{2}\right)(I-B)^{-1} Y
$$

This is the third and final movement of the interactive matrix process. Naming the effect-transfer matrix by $M_{a 1}$, the cross-effect matrix by $M_{a 2}$ and the circular-effect matrix as $M_{a 3}$, we have:

$$
M_{a 1}=(I-B)^{-1} ; \quad M_{a 2}=\left(I+D+D^{2}\right) ; \quad M_{a 3}=\left(I-D^{3}\right)^{-1}
$$

The global multiplier $\left(M_{g}\right)$ is given by the product of the three above mentioned multipliers, so as:

$$
M_{g}=M_{a 3} M_{a 2} M_{a 1}
$$

Replacing (10) in (2), we have the Leontief's fundamental equation changed in:

$$
Y=M_{a 3} M_{a 2} M_{a 1} Y=M_{g} Y
$$


These three multipliers, created by Pyatt and Round (1979), represent the following effects:

I) The direct and indirect effects from the transfer between activities from the same account set, therefore called by transfer-effect $\left(M_{a 1}\right)$;

II) The effects from the transactions between different account blocks, therefore called crossover-effect $\left(M_{a 2}\right)$; and

III) The effects from the transactions between blocks, therefore called circle-effect $\left(M_{a 3}\right)$.

An alternative model was developed by Stone (1985) that, unlike the model by Pyatt and Round (1979), presents his model with four additive components. This additive equation is derived from three substitution operations which development can be found at Santana (2004).

$$
M_{g}=I+\left(M_{a 3}-I\right)+\left(M_{a 2}-I\right) M_{a 1}+\left(M_{a 3}-I\right) M_{a 2} M_{a 1}
$$

where:

$I \quad=$ is the matrix of initial impulses;

$(M-I) \quad=$ it is matrix liquid-transfer effect Stone;

$(M-I) M_{a 1} \quad=\quad$ it is cross effect matrix Stone;

$(M-I) M_{a 2} M_{a 1} \quad=$ it is the matrix of cross-effect liquid Stone.

The Stone-transfer effect matrix allows one to calculate the indicators that capture the input-output transfer effects between productive activities and matches the array of global effects that captures inter-sectoral relations (Leontief Basic Matrix).

On the other hand, the cross-effect matrix Stone captures the economic impacts that result from the interactions that occur within and between the three accounts blocks of endogenous productive activities and the added value between value added and institutions and finally between institutions and productive activities. Finally, the matrix of circular effects captures the effects of exogenous stimulus in productive activities that are transmitted to the added values and for these institutions and their return to productive activities, closing the cycle. Hence, the importance of matrix decomposition of overall effects of Social Accounting Matrix remade in the three mentioned.

\section{ANALYSIS OF THE RESULTS OF APPLYING THE MODEL OF THE SOCIAL ACCOUNTING MATRIX OF THE BRAZILIAN AMAZON}

When the Social Accounting Matrix is analyzed it is not clear the concept of Financial Institutions, so it follows some clarification. Financial Institutions comprise 
a group of banking institutions and non-bank providers of financial services. The banking financial institutions develop fundraising activities inherent to the surplus agents and applying for loans or financing the deficit agents.

The gap of resources given by the value of the collection and the application corresponds to the profit of the banking financial institution due to one of its functions is to provide information. A second important function concerns the performance of banking financial institutions to reduce risks because lenders want to get more to take risks. A third function of banking financial institutions is to provide the issuance of any claims about themselves in order to satisfy the demand of those rights by the lenders.

In fact, the distinction between bank and non-bank financial institutions is to some extent artificial, however, the banking financial institutions are authorized by the Central Bank of Brazil to accept deposits and this makes the distinction. Demand deposits, for example, are registered bonds that generate a current account deposits which can be withdrawn at any time by check. In principle, deposits generate bonds that can be traded in financial markets, but in the same way that banking institutions operating in the credit market, credit societies, financing and investment, which are not banks, have done so.

On the other hand, investment banks do not act in the credit market, but on the capital market. Currently, however, multiple banks diversified their activities as service providers. Thus, as regards financial services, there are a variety of them, such as banking, trust services, brokerage services and custody services (custody).

\subsection{Sectoral analysis of the direct and indirect effects on the economy of the Brazilian Amazon}

Direct technical coefficients of the matrix represent both the value of inputs as the value added (products) required for a given economic activity to produce the equivalent of a unit of gross value of production (or GVP). These technical coefficients of inter-sectoral matrix $A$ capture the amount of inputs required to produce a quantity of products of a given industrial activity of the regional economy.

In 1999, the direct effects derived from the matrix of inter-sector flows, showed that for every $\mathrm{R} \$ 1,000.00$ of gross value of production generated by financial institutions in the Brazilian Amazon economy. Of this amount, are: the expenditure of about R \$ 76.80 to purchase services within the financial sector itself; R $\$ 150.90$ to purchase services sector "other services"; R\$ 16.50 of the telecommunication sector; $\mathrm{R} \$ 11.50$ in the transportation sector; $\mathrm{R} \$ 4.70$ in the cellulose industry, paper and graphic; R\$ 7.50 in the "other industries; $\mathrm{R} \$ 1.90$ trade sector; $\mathrm{R} \$ 4.0$ in the energy sector; $\mathrm{R} \$ 1.10$ in the education sector, as can be seen in Table 2. 
TABLE 2

AVERAGE PROPENSITY TO SPEND MATRIX OF MCS IN THE BRAZILIAN AMAZON: 1999

\begin{tabular}{|c|c|c|c|}
\hline \multirow{2}{*}{$\begin{array}{c}\text { Number } \\
\text { of }\end{array}$} & Production Description/Sector Description & \multicolumn{2}{|c|}{$\begin{array}{c}\text { Average propensity to spend matrix } \\
\text { of Social Accounting Matrix }\end{array}$} \\
\cline { 3 - 4 } Sector & & $\begin{array}{c}\text { Effect } \\
\text { Sale }\end{array}$ & $\begin{array}{c}\text { Effect } \\
\text { Purchase }\end{array}$ \\
\hline 1 & & 0.0055 & 0.0000 \\
2 & Agriculture & 0.0051 & 0.0000 \\
3 & Livestock & 0.0049 & 0.0000 \\
4 & Forest & 0.0283 & 0.0000 \\
5 & Mineral extraction & 0.0134 & 0.0000 \\
6 & Non-metallic mineral & 0.0101 & 0.0000 \\
7 & Metallic mineral & 0.0071 & 0.0000 \\
8 & Machines Equipments and automobiles & 0.0035 & 0.0000 \\
9 & Wood and furniture & 0.0091 & 0.0047 \\
10 & Cellulose, paper and graphic & 0.0068 & 0.0000 \\
11 & Textile, clothing and leather & 0.0087 & 0.0000 \\
12 & Vegetal Agribusiness & 0.0074 & 0.0000 \\
13 & Animal agribusiness & 0.0073 & 0.0075 \\
14 & Other industries & 0.0178 & 0.0040 \\
15 & Energy & 0.0047 & 0.0013 \\
16 & Health and sanitation & 0.0033 & 0.0000 \\
17 & Construction & 0.0213 & 0.0019 \\
18 & Trade & 0.0163 & 0.0115 \\
19 & Transport & 0.0169 & 0.0165 \\
$\mathbf{2 0}$ & Telecommunication & $\mathbf{0 . 0 7 6 8}$ & $\mathbf{0 . 0 7 6 8}$ \\
21 & Financial Institution & 0.0003 & 0.0011 \\
22 & Education & 0.0003 & 0.0055 \\
23 & Storage & 0.0060 & 0.1509 \\
\hline
\end{tabular}

Source: Made by the authors.

\subsection{Sectoral analysis of the transfer effects for the economy of the Brazilian Amazon}

The Social Accounting Matrix is important for structural analysis because makes endogenous social institutions and added value appropriated by them, but to measure the effects of exogenous variables on endogenous variables is necessary to partition the $A$ matrix in order to specify at least one of the accounts as exogenous, as previously shown. In the case of the Amazon economy, the exogenous accounts include flows from the exports of the region with the rest of the world and of Brazil, as well as the flow of net subsidies taxes.

The Social Accounting Matrix is important for structural analysis because endogenize social institutions and the value added by them appropriate. Because of this, the analytical power of Social Accounting Matrix is broader - as it involves all economic transactions in the market for goods and services and factor markets- than the Matrix Input-Output. However, to measure the effects of the exogenous variables on the endogenous variables you need to partition the matrix to specify at least one of the accounts as exogenous. 
Thus, in a partitioned array have been some columns representing endogenous activities and representing some other exogenous accounts. In the case of the Brazilian Amazon economy, exogenous accounts include flows of exports from the region to the rest of the world and Brazil, as well as taxes less subsidies flows. Starting from ma solving methodology adopted by Santana (2004), the lines of exogenous accounts of the matrix are excluded from the partitioned matrix and the columns of the exogenous accounts form the vector $X_{k}$ impacts $(k=a, i, v)$.

The array of effects-transfer Stone, which derives from the partitioned Social Accounting Matrix, is important to sector analysis because it captures the multiplier effects resulting from transfers of input-output relationships between and among the array of productive activities. Taking Table 3 as an analytical reference in the annex, it is noted that the financial institutions of the Brazilian Amazon economy impacted other regional economic activities and were also impacted by them. Indeed, we note that for the regional financial sector could meet an incremental stimulation of exogenous demand of $\mathrm{R} \$ 1,000.00$ in 1999 , financial institutions need to purchase inputs (financial services) within the financial sector itself in the amount of $\mathrm{R} \$ 85.60$ as reinforces the same Table 3 .

TABLE 3

TRANSFER-EFFECTS MATRIX OF STONE FOR THE BRAZILIAN AMAZON: 1999

\begin{tabular}{|c|c|c|c|}
\hline \multirow{2}{*}{$\begin{array}{c}\text { Number of } \\
\text { Sector }\end{array}$} & Production Description/Sector Description & \multicolumn{2}{|c|}{ Transfer-Effects Matrix of Stone } \\
\cline { 3 - 4 } & & Effect Sale & Effect Purchase \\
\hline 1 & Agriculture & 0.0087 & 0.0012 \\
2 & Livestock & 0.0082 & 0.0003 \\
3 & Forest & 0.0062 & 0.0002 \\
4 & Mineral extraction & 0.0354 & 0.0001 \\
5 & Non-metallic mineral & 0.0193 & 0.0003 \\
6 & Metallic mineral & 0.0175 & 0.0004 \\
7 & Machines, Equipments and automobiles & 0.1010 & 0.0018 \\
8 & Wood and furniture & 0.0080 & 0.0001 \\
9 & Cellulose, paper and graphic & 0.0151 & 0.0074 \\
10 & Textile, clothing and leather & 0.0130 & 0.0002 \\
11 & Vegetal Agribusiness & 0.0166 & 0.0005 \\
12 & Animal agribusiness & 0.0138 & 0.0005 \\
13 & Other industries & 0.0112 & 0.0133 \\
14 & Energy & 0.0294 & 0.0097 \\
15 & Health and sanitation & 0.0098 & 0.0023 \\
16 & Construction & 0.0066 & 0.0023 \\
17 & Trade & 0.0266 & 0.0063 \\
18 & Transport & 0.0212 & 0.0159 \\
19 & Telecommunication & 0.0200 & 0.0204 \\
$\mathbf{2 0}$ & Financial Institution & $\mathbf{0 . 0 8 5 6}$ & $\mathbf{0 . 0 8 5 6}$ \\
21 & Education & 0.0010 & 0.0014 \\
22 & Storage & 0.0050 & 0.0073 \\
23 & Other services & 0.0083 & 0.1761 \\
\hline
\end{tabular}

Source: Made by the authors. 
Another way to analyze the transfer-effects of the financial institutions on the other activities in the region is through the sectoral multiplier effects. Financial Institutions of the Brazilian Amazon, in terms of input purchases from other sectors in 1999, responded to an external demand variation of $\mathrm{R} \$ 1$ billion acquiring inputs of construction sector suppliers in the amount of $\mathrm{R} \$ 2.3$; $\mathrm{R} \$ 6.3$ trade sector; $\mathrm{R} \$ 7.3$ million of the storage industry; $\mathrm{R} \$ 9.7$ million in the electricity sector; $\mathrm{R} \$ 15.9$ million in the transport sector; $\mathrm{R} \$ 20.4$ million in the telecommunications industry; $\mathrm{R} \$ 176.1$ million in the sector "other services" as shown in Table 3.

This only confirms inter-sectoral connection of the Brazilian Amazon economy and the existence of relations financial that should be taken into account by sector policymakers adjusted to local clusters.

\subsection{Sectoral analysis of the circular effects on the economy of the Brazilian Amazon}

The results of matrix-round effects on the economy of the Brazilian Amazon are shown in Table 4. Note that these results reveal the circular flow of said matrix, i.e., this matrix shows the effects departing from productive activities and flow to the value added and leave this to the institutions in the form of income that ultimately is spent on the purchase of goods and services produced by productive activities, thus closing the cycle.

It is through the circular-effect that the initial injection of an exogenous variable is spread throughout the economy and the result is manifested at a more advanced development stage of a regional economy. The results listed in Table 4 of the circulareffects matrix shows the impact of inter-sectoral multipliers that are derived from certain economic transactions that the Input-Output Matrix fails to get.

This advantage of the circular-effects matrix results from the fact that the part of the gross production value, which exceeds the purchase of inputs for a given activity, is converted into income and is spent, via circular effect, during acquisition of new consumer goods and new capital goods from productive activities. The same interpretation pattern can be applied to Financial Institutions.

Indeed, for a R\$ 1 billion increase in exogenous demand in 1999 led to the financial institutions of the Brazilian Amazon economy had spent on purchase of inputs - financial services in general, including deposit-taking in 1999, a total of approximately $\mathrm{R} \$ 84.5$ million in the sector of agriculture; $\mathrm{R} \$ 126.2$ million in the livestock sector; R \$ 93.7 million in the agribusiness sector of the plant; R\$ 123.7 million in the agribusiness sector animals; R 236.1 million in the sector "other industries"; $\mathrm{R} \$ 146.7$ in the electricity sector; and $\mathrm{R} \$ 121.2$ million within the financial sector itself, as confirmed by Table 4.

That same year, by contrast, the financial institutions of the Brazilian Amazon sold their financial products and services to all sectors with whom they negotiate. Among these sectors should be highlighted: Agriculture (R \$ 74.2 million); Livestock ( $\mathrm{R}$ \$ 69.7 million); Forest ( $\mathrm{R}$ \$ 88.1 million); Non-metallic minerals ( $\mathrm{R} \$ 90.9$ million); Metallic minerals ( $\mathrm{R} \$ 69.4$ million) and education ( $\mathrm{R} \$ 134.3$ million), as confirmed by Table 4 . 
TABLE 4

CIRCULAR-EFFECTS MATRIZ OF STONE FOR THE BRAZILIAN AMAZON: 1999

\begin{tabular}{|c|c|c|c|}
\hline \multirow{2}{*}{$\begin{array}{c}\text { Number of } \\
\text { Sector }\end{array}$} & \multirow{2}{*}{ Production Description/Sector Description } & \multicolumn{2}{|c|}{ Circular-Effects Matrix of Stone } \\
\cline { 3 - 4 } & Effect Sale & Effect Purchase \\
\hline 1 & Agriculture & 0.0742 & 0.0845 \\
2 & Livestock & 0.0697 & 0.1262 \\
3 & Forest & 0.0881 & 0.0026 \\
4 & Mineral extraction & 0.0821 & 0.0036 \\
5 & Non-metallic mineral & 0.0909 & 0.0264 \\
6 & Metallic mineral & 0.0694 & 0.0213 \\
7 & Machines, Equipments and automobiles & 0.0646 & 0.0754 \\
8 & Wood and furniture & 0.0881 & 0.0171 \\
9 & Cellulose, paper and graphic & 0.0810 & 0.0303 \\
10 & Textile, clothing and leather & 0.0690 & 0.0106 \\
11 & Vegetal Agribusiness & 0.0764 & 0.0937 \\
12 & Animal agribusiness & 0.0722 & 0.1237 \\
13 & Other industries & 0.0678 & 0.2361 \\
14 & Energy & 0.0924 & 0.1467 \\
15 & Health and sanitation & 0.1039 & 0.2380 \\
16 & Construction & 0.0850 & 0.4148 \\
17 & Trade & 0.0859 & 0.2557 \\
18 & Transport & 0.0797 & 0.1755 \\
19 & Telecommunication & 0.1041 & 0.1171 \\
$\mathbf{2 0}$ & Financial Institution & $\mathbf{0 . 1 2 1 2}$ & $\mathbf{0 . 1 2 1 2}$ \\
21 & Education & 0.1343 & 0.3121 \\
22 & Storage & 0.0882 & 0.1330 \\
23 & Other services & 0.1137 & 1.6009 \\
\hline
\end{tabular}

Source: Made by the authors.

Through the obtained results, it was found that the resulting cross-sector multiplier effect circular-are more robust than the multiplier effects of the transfer for the reasons stated.

\subsection{Sectoral analysis of the overall effects for the economy of the Brazilian Amazon}

Output is necessary to recall that the purpose-global matrix comprises the sum of the effects of the transfer matrices, cross and circular analyzed. The array of global-effects shows all direct and indirect impacts of some variation of exogenous demand.

The matrix of the overall effects derived from the Social Accounting Matrix, is completely conditioned by exogenous demand, as in Keynesian models, since there 
is no restriction of supply that is taken for granted. In fact, in each experimental situation in order to analyze the impact of exogenous variables on the endogenous variables, the shock always comes from external demand. The multipliers-global matrix effects are therefore are sensitive to the choice of vector exogenous demand, in the same way as the realism of the model results depends on the question chosen for analysis. A certain length of this line can be developed through the structural analysis steps multipliers.

The Table 5 shows the global impacts caused by unit changes in exogenous demand for goods and services sectors of the economy of the Brazilian Amazon resulting from cross-sector economic interactions (shown on the main diagonal), with the network providers that reveals the effects back (presented in columns) and also with the customer network that reveals the effects forward (presented in lines).

To start analysis, becomes only the column 20 of the array of global multipliers of the economy of the Brazilian Amazon, year 1999 corresponding financial institutions or Financial Sector, as can be seen in Table 5. In this column, it is clear that an increase to one billion reais in exogenous demand for financial products and services in the financial sector, caused an additional increase of approximately $\mathrm{R} \$ 206.80$ million in the financial sector itself which, added to a 1 million actual initial injection totaling $\mathrm{R} \$ 1,206.8$ million. The results analyzed column 20 of Table 5 indicate that the financial industry located in northern Brazil has a reasonable amount to boost capacity in the case of a provider of financing activity and loans for other activities.

Table 5 plus the coefficients of intra-sectoral multipliers, other important intersectoral increases in demand for inputs from the regional financial sector spread up to other economic activities, as a result of initial injection of one billion reais, such as: $\mathrm{R} \$ 85.7$ million for agriculture; $\mathrm{R} \$ 126.5$ million for livestock; $\mathrm{R} \$ 156.3$ million at the electricity sector; $\mathrm{R} \$ 417.1$ million for construction and $\mathrm{R} \$ 1,777.1$ million for the sector "other services", as shown in column 20 of Table 5.

These values reflect the expansion required for each economic sector to meet the demand of unit increments. It follows, therefore, that the incentives caused by increased exogenous demand not induce despite variations of the magnitudes of the coefficients of inter-sectoral links, only the growth of individual activities, but also of the Brazilian Amazon economy as a whole.

It is also important to observe the impacts caused by global multipliers on institutions and on the income distribution of the Brazilian Amazon economy sectors, in particular of Financial Institutions. Indeed, the exogenous demand increase in $\mathrm{R} \$ 1.0$ billion spread direct and indirect multiplier effects on the institutions (families, enterprises and government). For the financial sector case, the increase demand for consumer goods in 2000 was of $\mathrm{R} \$ 2,010.0$ million, which, added to the initial injection of $\mathrm{R} \$ 1,000.0$ million, increased global demand for consumer goods of the Brazilian Amazon economy in $\mathrm{R} \$ 3,010.0$ million. 
TABLE 5

MATRIX GLOBAL-EFFECTS OF THE BRAZILIAN AMAZON: 1999

\begin{tabular}{|c|c|c|c|}
\hline \multirow{2}{*}{$\begin{array}{c}\text { Number of } \\
\text { Sector }\end{array}$} & Production Description/Sector Description & \multicolumn{2}{|c|}{$\begin{array}{c}\text { Matrix Global-effects of the } \\
\text { Brazilian Amazon }\end{array}$} \\
\cline { 3 - 4 } & & 0.0828 & 0.0857 \\
\hline 1 & Agriculture & 0.0779 & 0.1265 \\
2 & Livestock & 0.0943 & 0.0028 \\
3 & Forest & 0.1175 & 0.0036 \\
4 & Mineral extraction & 0.1101 & 0.0267 \\
5 & Non-metallic mineral & 0.0870 & 0.0217 \\
6 & Metallic mineral & 0.0747 & 0.0772 \\
7 & Machines, Equipments and automobiles & 0.0961 & 0.0172 \\
8 & Wood and furniture & 0.0961 & 0.0377 \\
9 & Cellulose, paper and graphic & 0.0820 & 0.0109 \\
10 & Textile, clothing and leather & 0.0930 & 0.0942 \\
11 & Vegetal Agribusiness & 0.0860 & 0.1242 \\
12 & Animal agribusiness & 0.0790 & 0.2494 \\
13 & Other industries & 0.1218 & 0.1563 \\
14 & Energy & 0.1137 & 0.2403 \\
15 & Health and sanitation & 0.0916 & 0.4171 \\
16 & Construction & 0.1125 & 0.2620 \\
17 & Trade & 0.1009 & 0.1915 \\
18 & Transport & 0.1241 & 0.1375 \\
19 & Telecommunication & $\mathbf{1 . 2 0 6 8}$ & $\mathbf{1 . 2 0 6 8}$ \\
$\mathbf{2 0}$ & Financial Institution & 0.1352 & 0.3135 \\
21 & Education & 0.0932 & 0.1403 \\
22 & Storage & 0.1220 & 1.7771 \\
23 & Other services & 0.1433 & 3.0100 \\
24 & Families & 0.0584 & 0.6903 \\
25 & Brutal Fixed Capital Formation & 0.1433 & 2.0374 \\
26 & Wage & 0.1010 & 1.3850 \\
27 & Profit & & \\
& & & \\
\hline
\end{tabular}

Source: Made by the authors.

In addition, corporate institutions and government were also negatively impacted as the same magnitude of the initial injection led to an increase in brutal fixed capital formation of only R $\$ 690.3$ million, as shown in column 20 of Table 5. The effects of the global multipliers have spread also on the level and income distribution of the Brazilian Amazon.

These economic impacts were captured by increase in the level and distribution of added value -expressed in the form of wages and profits- generated by financial institutions located in the northern region of Brazil. Indeed, it is noted that in 1999, the value added of the financial sector increased as a result of the initial injection of one billion reais, for a total of $\mathrm{R} \$ 3,422.4$ million. This value, about $59.53 \%$ were appropriated by the working class in the form of wages; and $40.70 \%$ for the business class in the form of profits, as can be seen in column 20 of Table 5. 
Another way of interpreting the global multiplier effects derived from the Social Accounting Matrix of the Brazilian Amazon economy in 1999 can be made from the response issued by a given activity elected to the stimulus caused by a unitary and simultaneous injection to other productive activities downstream.

In this case, the reading of the overall multiplier-global matrix effects is performed along the lines of Table 5, where in 1999, a unique injection of a billion reais caused by exogenous demand has resulted in an overall multiplier effect on the financial institutions in terms of sales of financial products and services, ranging from a minimum of R $\$ 74.7$ million of the production machinery industry, equipment and vehicles, to a maximum of approximately $\mathrm{R} \$ 1,206.8$ million within the financial sector itself as indicated in line 20 of Table 5.

These results indicate that the financial industry responded in 1999 to demand more strongly impacts within the activity. This only reinforces the immediate need for a national regional financial sector development policy in order to add more value to products and services in the financial sector of the Amazonian economy in order to strengthen further the relations of interdependence between the financial sector and other productive sectors the Amazon region.

This variability of global multiplier effects is a factor that can limit the improvement of income distribution and employment structure of the regional economy. To mitigate this situation we need to know more deeply the conditions of regional production structure to prevent, by agents, certain decisions that penalize the poorest economic sectors and/or block those channels that can facilitate sustained economic growth of the Amazon economy Brazilian.

In short, this variability implies that the overall multiplier effects in the economy of north of Brazil depend on the regional demand structure; and that the expenditures of economic agents in the procurement of goods and consumption and investment services differ from company to company and consumer to consumer. The robustness of intra and inter-sectoral relations generated within and between the financial sector and other activities of the industry supply chain, especially those closest Financial Institutions upstream and downstream, reveals the structural power of a key industry.

Apparently here in 1999, the Financial Institutions responded to stimuli of all activities of its chain with emphasis on the sectors of the mining industry, agriculture, civil construction, "other services" and "other industries". The degree of weak robustness of the overall multiplier of the financial sector, to the majority of the Amazon economy sectors indicates that the regional financial sector does not have a strong power of drag on the growth of other regional productive activities to trigger a process of financing for Development a la Hirschman in the Brazilian Amazon.

\subsection{Analysis of the Keynesians multiplier effects}

To analyze the real ability of the sectors generating product Amazon economy, employment and income sector, it will make use of the multipliers of product concepts, employment and income (wages and profits). These multipliers capture the product of generation capacity, employment and income, directly and indirectly, through the exogenous unit increase in demand and also were calculated from the array of global 
multiplier effects $\left(M_{g}\right)$ and their vectors-column and row vectors of the variables considered: product, employment and income.

\subsubsection{The product multiplier}

The product multiplier $\left(M P_{j}\right)$ is derived from the equation:

$$
M P_{j}=\sum_{i=1}^{n} A_{i j}
$$

Where $A_{i j}$ are the coefficients of direct and indirect effects of the $M_{g}$ columnvectors, which measures the variation of the total output of all productive sectors of the Amazon economy in response to variations of a monetary unit of final demand for products of a specific sector considered for analysis.

In the case of financial institutions, the multiplier of 5.7202 order product suggests that in 1999, an increase to $\mathrm{R} \$ 1$ billion of final demand, financial institutions responded with an increase of approximately $\mathrm{R} \$ 5,7202$ million inputs (financial products and services) to meet this increase in final demand, as can be seen in Table 6 in the next section.

The financial sector multiplier product is one of the strongest among the sectors of the Amazon economy, including standing up average product of the multiplier (4.5556) of the regional economy, as confirmed by Table 6 .

\subsubsection{The employment multiplier}

The sectoral employment multiplier $\left(M E_{j}\right)$ is derived from the formula:

$$
M E_{j}=\frac{E_{j}}{e_{j}}
$$

Where: $E_{j(1 \times 23)}=e_{j(1 \times 23)} \cdot M_{g(23 \times 23)}$

It means that $E_{j}$ represents the direct and indirect employment coefficients calculated by the previous multiplication of the vector-line of direct employment $(e j)$ by the direct and indirect coefficients of the global effects matrix $\left(M_{g}\right)$. Therefore, the employment multiplier measures the capacity of employment generation in each sector in response to exogenous variation of a monetary unit of the final demand.

In the case of financial institutions, the employment multiplier is 19.8506 of order, so one of the strongest of the Brazilian Amazon economy. This means that for an exogenous increase of $\mathrm{R} \$ 1$ billion of final demand, the financial sector of the economy of the region responded with a generation of direct and indirect jobs in 1999, around 19.851, so well above the regional average, as confirms Table 6 in the next section.

These indicators confirm the strategic importance of regional financial sector to leverage the development of the Amazon in Brazil. 


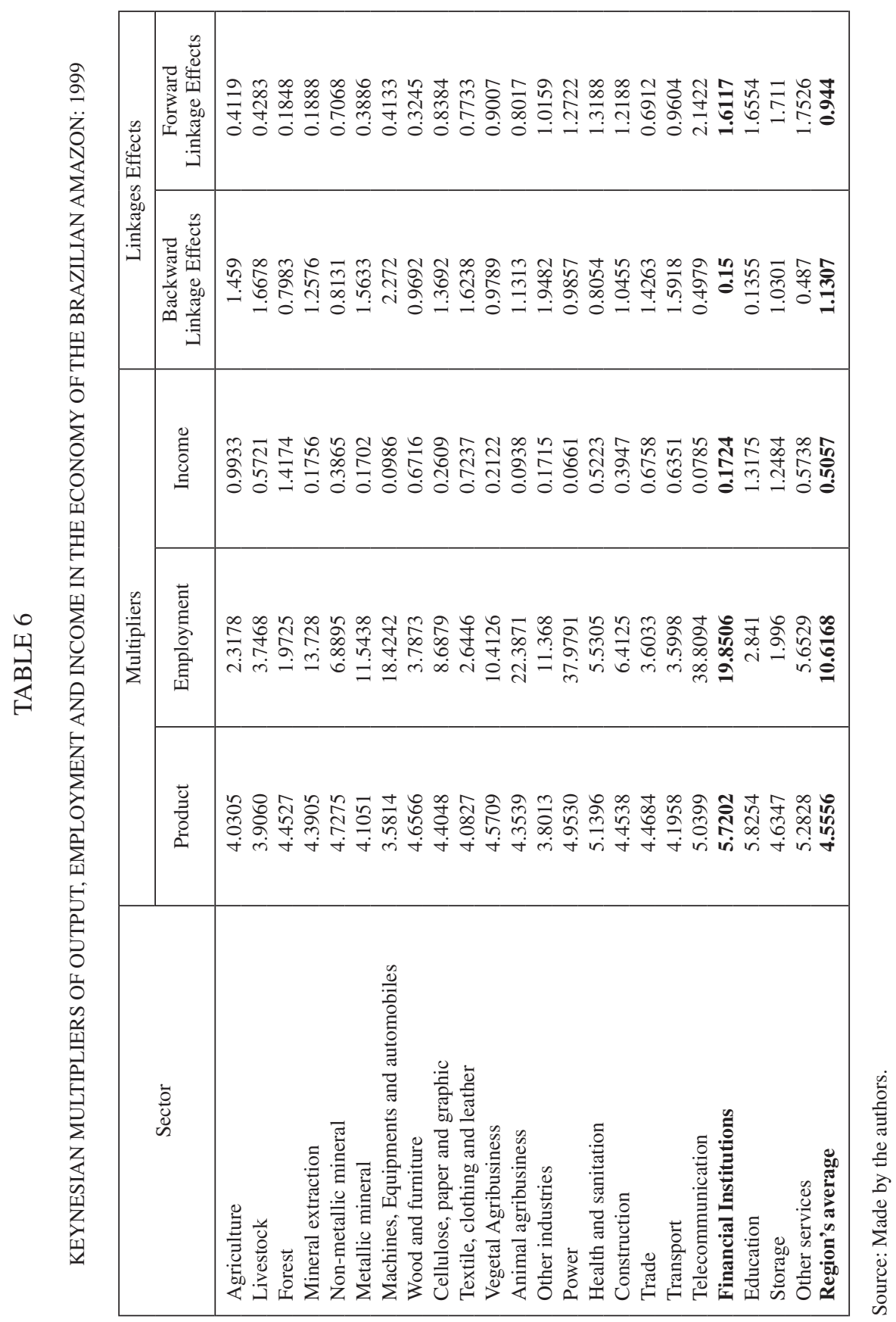




\subsubsection{The income multiplier}

The sectoral aggregate income multiplier $\left(M R_{j}\right)$ is derived from the equation:

$$
M R_{j}=\frac{R_{j}}{r_{j}}, \text { Wherein: } R_{j(1 \times 23)}=r_{j(1 \times 23)} M_{g(23 \times 23)}
$$

This means that the calculation of the income multiplier $\left(M R_{j}\right)$ is obtained by dividing the values of the vector-line of income (salaries plus profits) direct and indirect effects of the global-effects matrix $\left(R_{j}\right)$ by the values of the vector-line income direct coefficients $\left(r_{j}\right)$.

In the case of the financial sector of the economy of the Brazilian Amazon, there is the multiplier of the aggregate income is relatively low, even falling below the regional average when compared with other sectors with greater power of generating income. Indeed, for an increase of $\mathrm{R} \$ 1$ billion in final demand, the financial sector in the region responded with an increase of only $\mathrm{R} \$ 172.4$ million in income, as shown in Table 6.

\subsection{Analysis of the linkages backward and forward effects}

In this section, we discuss the economic impacts of interconnections between various activities of the Social Accounting Matrix 1999 of the Brazilian Amazon economy. In the face of inter-regional income inequalities, one of the goals of regional economies of the Brazilian periphery is to obtain a quick income growth.

To do this, industrialization and regional agro-industrialization may help reduce the economic gap between the rich and poor regions. In this context, it is very important to choose the regional economic development strategy due to lack of resources to operate a volume of broad and diversified investment. In this regard, it should be considered the border of the debate on the most appropriate criteria for choosing the productive activities of greater capabilities to leverage regional economic growth.

In this respect, it is important to know the intensity of linkage effects back and forth of productive activities in the Amazon, as one of those criteria for the choice of the most power of leverage key industries. The theoretical framework that guides decision-making of economic agents about the choice of the most appropriate strategy pro-economic development, balanced growth versus unbalanced growth is already well known. Indeed, the concepts of linkages effects backward (retrospective) and forward (prospective) were developed by Hirschman (1961).

Nevertheless, the necessary technique to measure the induced direct and indirect effects on the regional economy was developed by Rasmussen (1963). The inverse Matrix of Social Accounting, $M$ is the reference matrix for measuring inter-sectoral linkages. The choice of this alternative due to the fact that the Social Accounting Matrix incorporate, besides the intermediate demands (inputs), final demands by consumer spending and investment, and the income of the factors of production and its distribution between the institutions. 
Therefore, the coefficients of the linkages derived from the Social Accounting Matrix are more robust than the input-product matrix, as they capture all direct and indirect effects of exogenous changes in final demand for all sectors of the regional economy.

\subsubsection{Determining method of the chaining effects coefficients}

The identification of key-industries in a regional economy is made through the analysis of the backward $\left(U_{j}\right)$ and forward $U_{i}$ linkage effects coefficients from the Social Accounting Matrix for the year 1999 of the Brazilian Amazon economy.

These effects are defined as follows:

1) $U_{j}=\left[\left(M_{a j} / n\right) / \overline{M_{a}}\right]$

Wherein $U_{j}$ measures the backward linkage effect;

$M_{a j}$ is the coefficients sum of a given column $j$ of the inverse Social Accounting Matrix of $M$;

$\bar{M}_{a}$ is the average of all $M a$ matrix elements.

2) $U_{i}=\left[\left(P_{a i} / n\right) / \overline{P_{a i}}\right]$

wherein $U_{i}$ measures the forward linkage effect,

$P_{a i}=$ is the sum of the coefficient of a determinate line $i$ of inverse Social Accounting Matrix;

$\overline{P_{a}}=$ is the average of all elements of the $P_{a}$;

$n=$ is the number of productive activities of the reverse Social Accounting Matrix.

Since the average $\left(M_{a j} / n\right)$ show the intermediate inputs purposes, if the final demand $j$ productive activity increment of a unit, then $U_{j}>1$ indicates that productive activity to that already relies heavily on inputs produced in other productive activities, and vice versa where $U_{j}<1$. This coefficient that captures the backward chaining effect was developed by Rasmussen (1957) and accepted by Hirschman (1961) found that as a good indicator to identify key industries for developing economies.

As for the coefficient that captures the forward chaining effect, this was developed by Jones (1976) which uses an array $m$ product coefficient $P$ in place of the technical coefficients used in the model Rasmussen (1957). According to Santana (2004), to facilitate the interpretation of the ranking of the key sectors of the economy of the Brazilian Amazon, both coefficients back and forth were normalized by the global industry average

The Activities or industries that have high linkage effects backwards $\left(U_{j}>1\right)$ and forward $\left(U_{i}>1\right)$ are those who should have greater power to induction of the product of a given regional economy through the external economies generated by demand or supply-side economics. 


\subsubsection{The method of determination of the coefficients of linkage effects}

Taking the Table 7 as a reference, it is clear that in 1999, there were three productive activities with linkages effects backwards and forwards greater than unity. That same year, the financial institutions located in the Brazilian Amazon presented an index of the bonding effect backwards $\left(U_{j}=0.1500<1\right)$ lower the unit. Therefore, financial institutions in the Brazilian Amazon economy have low connection power back to the productive activities situated upstream of its position, as shown in Table 7.

Still to Table 7, it is noted that the financial institutions of the region have an index of the bonding effect forward $\left(U_{i}=1.6117>1\right)$ greater than unity. This means that the financial sector in the region is connecting more with the activities downstream of its position in the economic structure of the region. Thus, it is strengthening over the final demand for its financial products and services by productive activities and social institutions.

TABLE 7

BACKWARD LINKAGE EFFECTS AND FORWARD LINKAGE EFFECTS OF ECONOMIC SECTORS, ESPECIALLY OF FINANCIAL INSTITUTIONS OF THE BRAZILIAN AMAZON: 1999

\begin{tabular}{|l|c|c|}
\hline \multirow{2}{*}{ Sector } & \multicolumn{2}{|c|}{ Linkages Effects } \\
\cline { 2 - 3 } & Backward Linkage Effects & Forward Linkage Effects \\
\hline Agriculture & 1.459 & 0.4119 \\
Livestock & 1.6678 & 0.4283 \\
Forest & 0.7983 & 0.1848 \\
Mineral extraction & 1.2576 & 0.1888 \\
Non-metallic mineral & 0.8131 & 0.7068 \\
Metallic mineral & 1.5633 & 0.3886 \\
Machines, Equipments and automobiles & 2.272 & 0.4133 \\
Wood and furniture & 0.9692 & 0.3245 \\
Cellulose, paper and graphic & 1.3692 & 0.8384 \\
Textile, clothing and leather & 1.6238 & 0.7733 \\
Vegetal Agribusiness & 0.9789 & 0.9007 \\
Animal agribusiness & 1.1313 & 0.8017 \\
Other industries & 1.9482 & 1.0159 \\
Power & 0.9857 & 1.2722 \\
Health and sanitation & 0.8054 & 1.3188 \\
Construction & 1.0455 & 1.2188 \\
Trade & 1.4263 & 0.6912 \\
Transport & 1.5918 & 0.9604 \\
Telecommunication & 0.4979 & 2.1422 \\
Financial Institutions & 0.15 & 1.6117 \\
Education & 0.1355 & 1.6554 \\
Storage & 1.0301 & 1.711 \\
Other services & 0.487 & 1.7526 \\
Region's average & 1.1307 & 0.944 \\
\hline
\end{tabular}

Source: Made by the authors. 
Consequently, the Financial Institutions in the Amazon economy have low backward linkage power to productive activities located upstream of its position. By the same table, note that the Financial Institutions of the region have an index of the forward linkage effect $\left(U_{i}=1.6117>1\right)$ greater than unity.

This means that the region's financial sector is connecting more and more with the activities of the downstream position in the economic structure of the region, it means, it is strengthening final demand for their products and financial services by the productive activities and social institutions part.

Because of this the behavior of indices that capture the links of effects back and forth of productive activities in the Brazilian Amazon, despite the stabilization policy of the federal government and discretionary economic growth policy by forced marches that penalizes some productive activities to the detriment other, most sectors of the regional economy had expanded their structural economic relations, as shown in Graph 1 and Graph 2.

The fragility of the backward linkages effects in the financial sector may have some validity under certain historical conditions exclusionary regional development that is just waiting for the exclusive logic of the market performance. However, in a

\section{GRAPH 1}

\section{BACKWARD LINKAGES EFFECTS OF SOCIAL ACCOUNTING MATRIX OF THE BRAZILIAN AMAZON: 1999}

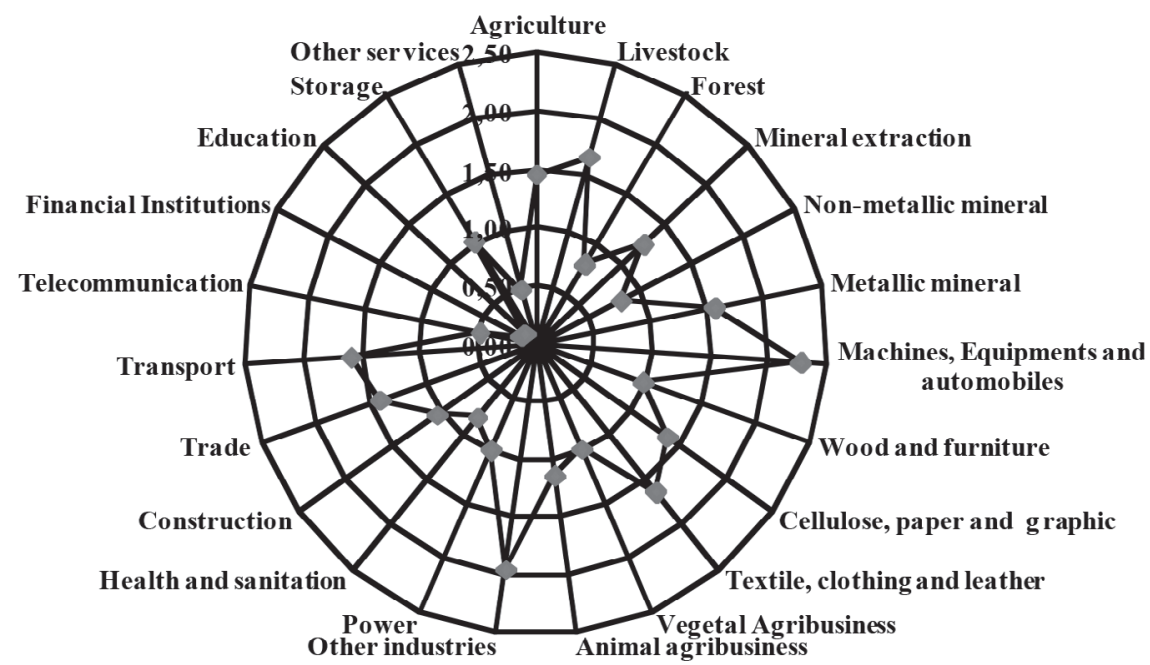

- Backward Linkage Effect

Source: Made by the authors. 
regional economy where the state is present with investments in basic social capital, allocation of tax credit and incentives, besides the purchasing power of state enterprises, the combined effects of these pro-development tools can overcome this inertia and enable strategic private investment generator of scale economies, scope economies and external economies by increasing the industrial plant, the product differentiation and the deepening of vertical integration - through the market' support, especially in the current globalization context.

The level of structural interdependence among the productive activities of the region's economy, can be derived both from the inputs offer from other activities to the considered productive activity -causing the backward effects- as from demand for products of this considered activity, by other activities, allowing the emergence of forwards effects. Moreover, regional economic development can be stimulated by the forces of final demand connections, according to the Keynesian tradition, associated with the income structure (added value) which, in turn, binds to the regional productive structure, through social institutions, closing the circular flow specified by the Social Accounting Matrix of the Brazilian Amazon 1999.

\section{GRAPH 2}

\section{FORWARD LINKAGES EFFECTS OF SOCIAL ACCOUNTING MATRIX OF THE BRAZILIAN AMAZON: 1999}

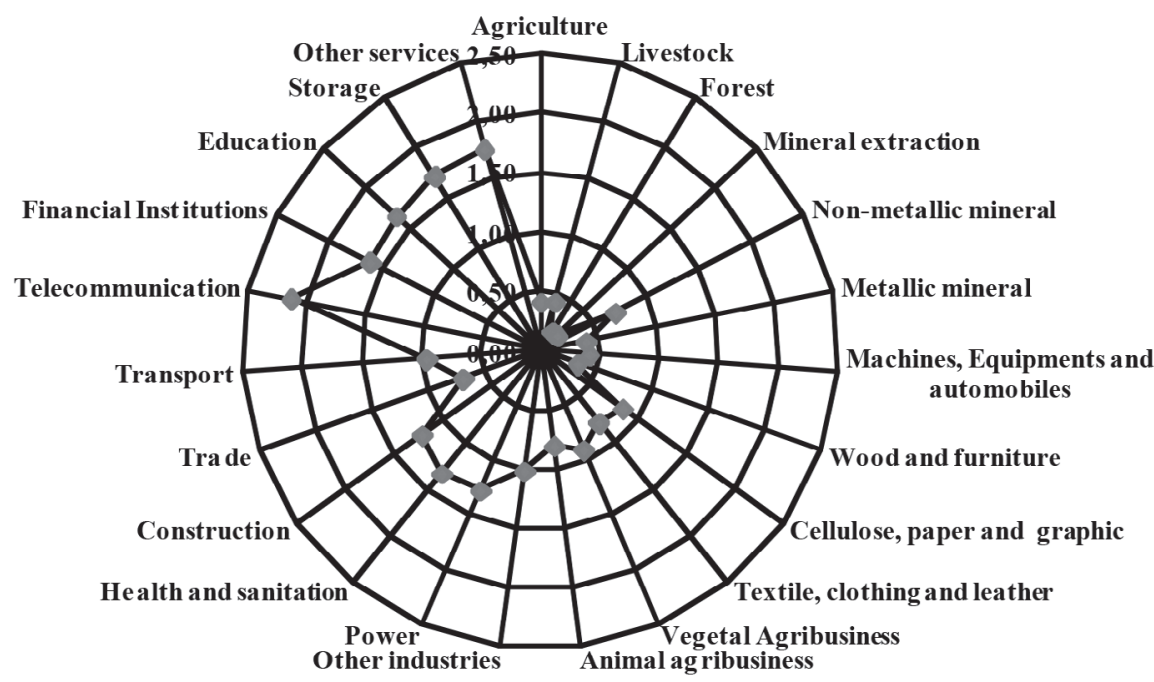

\section{—-Forward Linkage Effect}

Source: Made by the authors. 


\section{CONCLUSION}

This work can be seen that the current trend of bank concentration in big cities limits the financing of investments in the regions of the national periphery, and therefore the economic development of the Brazilian Amazon. The process of financial concentration in the center also helps to expand the industrial concentration in the Southeast given the conventional base of credit to the activities of the periphery.

Therefore, the analysis highlights the need for government intervention to prevent the continuation of this perverse process concentrator of wealth and income in Brazil. The financial dimension of regional issue, particularly in northern Brazil, deserves to enter the government agenda among other reasons by the constitutional need for the federal pact seek national integration, not least because the own Ministry of National Integration was established for that.

In addition to the strong banking and financial flows in the center-center and center-periphery is need to strengthen the fragile banking and financial flow in the center-periphery direction through an integrated economic policy that reconciles systemically macroeconomic policies -monetary, fiscal and foreign exchange- with sectoral policies (industrial, agricultural, commercial and technological innovations) and regional policies for sustainable development.

But, it is necessary that the integrated actions of these economic policies are coordinated by planning agencies of the regions of the periphery. In turn, domestic banks and regional, public and private, should be subject to appropriate regulations to which may play an important role in contributing to regional development in order to reduce the gap between the center and the periphery as predict the article 192 Constitution of the Federative Republic of Brazil.

In the economy of the Amazon, productive activities establish a network transactions and economic relations of intra and inter-sectoral nature. In the case of financial activities that operate in the Brazilian Amazon the rule is the same, so the quantitative understanding of the economic importance of these economic relations can become a powerful planning tool to guide decisions of private agents and the federal government itself with regard to the implementing economic policies geared to the development of the regional economy.

In this work, the main objective was to measure and interpret the effects caused by the financial institutions on the other sectors of the Brazilian Amazon economy in terms of economic impacts raised by the transfer matrices, cross, circular and global, when subjected to an exogenous unit change of final demand. There was also the need to seek the quantification and analysis of the effects caused by these financial institutions on other productive activities of the Amazonian economy, in terms of product creation, income generation and employment.

In addition, we attempted to analyze, for identification of the Amazon key industries, the linkage effects back and forth caused by financial institutions upstream and downstream of the production chain of financial services. To meet these goals, there was use of Social Accounting Matrix of the Brazilian Amazon economy of 1999. We adopted the matrix modeling technique to calculate the appropriate economic indicators from the Social Accounting Matrix. 
Through these economic indicators, it was then possible to measure trade flows of productive activities and views the conditioning factors that influence the sectoral fluctuations in the Amazon economy. An analysis by the demand side provides information on the various economic agents of the Brazilian Amazon interact-families, businesses, government and the rest of the world- to you and to each other so as to constitute an aggregate market demand for financial firms and non-financial meet. An analysis on the supply side of goods and services requires that the activities are able to employ the factors of production, capital and labor in sufficient quality and quantity to produce the goods that have demand in the market.

In the Brazilian Amazon, the shortage of available supply of skilled labor and additions and renovations to gross capital stock, via investment, limit the amount of production that may be destined for the end market. Meanwhile, the economic connection between supply and demand markets, are the various intermediate transactions that define the technological standard of the regional economy. Understanding these limits to the Brazilian Amazon's economic growth is of paramount importance, since exogenous variations of final demand directly and indirectly affect the sectors of the economy and the efficient allocation of resources.

In general, financial institutions that operate in the Brazilian Amazon economy is integrated with other productive activities that end up playing a range of significant results necessary for the preparation of viable planning strategies for the Amazon development. This work can be seen that the Social Accounting Matrix Amazon in 1999 can be used to support the development theory of Hirschman. To this end, the Amazon economy is theoretically designed based on the concepts of gross production value, value added and income distribution; all these concepts articulated the operating dynamics of the circular flow and sectoral productive chains.

The Model Social Accounting Matrix provides a structural view of the economy of northern Brazil to allow optimization, via multiplier effects and linkage effects back and forth, the development of interconnected sectors. This alternative model the Input-Output Matrix also facilitates the understanding of the impacts of macroeconomic policies, sectoral policies and by the regional policies in the regional economy as a whole.

In the case of the financial sector, the linkage effects are weak back and forward linkage effects are robust enough to trigger effective sequences to other chains, especially in the application and obtaining loans. Still, it can be said that the financial industry in the Brazilian Amazon, by submitting their knock-on effects backward $\left(U_{t}<1\right)$ and forward $\left(U_{f}>1\right)$ incomplete still do not constitute a key industry in the sense of author, Hirschman.

The matrix of global multipliers derived from the Social Accounting Matrix, was broken down into three partitioned matrices: the matrix-transfer effect that captures the technical input-output relations; the matrix-cross effect, which captures the impacts transmitted between blocks of different activities; and end-circular array, that captures the distribution of the results within the economy.

In this regard, it can be said that Amazon's productive structure in 1999, especially regarding the studied sector, it is still a reflection of the low level of intersectoral concatenations able to allow the functioning of the economy in other bases. In addition, the inefficient conduct of regional policy of financial incentives and 
credit of the government banks, financing individual projects without intra and inter concatenations, instead of funding clusters and structural clusters of supply chains in the Amazon region, certainly over causing an underperforming the GDP growth per capita in the Brazilian Amazon in recent years. This is made evident when we compare the economic impacts of the global multipliers and inter-sectoral links the various production activities in the region.

Regional policy of tax incentives in the Brazilian Amazon acted selectively and partially on the basis of purely political criteria and not by clear rules based on technical and economic criteria. Therefore, this policy did not attract the driving industries promoters of the effects of attraction to the formation of industrial and agricultural complexes that could sustain a wave of further industrialization able not only to promote economic growth, as disseminate it to all economic agents in the form of distribution of income and employment. In fact, the national regional development policy was distorted to the extent that only favored primary production and human occupation without regard to the need for the formation of generating productive chains of external economies.

The impact of the multiplier effect of public investment, particularly in energy, although important not unleashed centrifugal forces of attraction for activities that generate sequential pulses able to radiate economic growth around the production chains in industrial areas as recommended by the Development Plans Brazilian Amazon. The decomposition of the matrix of global multiplier effects in the economy of the region, transfer effects, cross and circular, reveals a distributive structure of the income and own regional employment a primary export economy based on the transfer effect also plays an important role. Through the analysis of indicators of the Social Accounting Matrix, is visible from the integration point of view, that process of horizontal integration of the productive sector (intra-sectoral) in the Brazilian Amazon has advanced, however, and productive vertical integration (inter-sectoral) is still insufficient.

Despite the improvement in the trade balance of the Brazilian Amazon with the rest of the world over the last twenty years, yet the terms of trade are unfavorable to the region. This translates, in a way, maintaining economic dependence of the region since the law of deteriorating trade prevents this situation is broken, via adoption of more efficient technologies, as this mechanism has just draining of the income generated internally in region to the rest of Brazil and the world.

To break this technological and economic dependence it is necessary to set, and a national policy for development of technological innovations at the regional level, a new national regional development policy that favors the formation of integrated supply chains and a trade policy that stimulates one agenda of broad and diversified export products with high added value so that the benefits arising there can be internalized in the form of income and employment by economic agents in the Amazon region.

It should be noted that with the Law Kandir the northern economy no longer rely on a fiscal mechanism for compensating the extraction and export of its non-renewable resources. In fact, the mineral export base states were virtually no tax mechanism to finance the attractive economic and social investment companies that have the ability to verticalize production are located in areas where extractive companies. 
In the Brazilian Amazon we can see that the degree of structural interdependence between the productive activities of the regional economy can be derived from both the supply of inputs of other activities to productive activity considered, giving the effects back as the product demand this activity considered by other activities, allowing the emergence of the effects forwards.

Moreover, regional economic development may be stimulated by the forces connections involving the final demand, according to tradition Keynes, income associated structure (added value) which, in turn, binds to the regional productive structure via social institutions, closing the circular flow specified by the Social Accounting Matrix 1999. This shows that the financial sector is able to establish strong linkages backwards and forwards with other regional productive activities and should therefore, be one of the key activities of the Brazilian Amazon economy that should be considered important to the sustainable development of the region Northern Brazil.

\section{REFERENCES}

AMADO, A.M. (1999). "Moeda, Sistema Financeiro e Trajetória de Desenvolvimento Regional Desigual". In: Sicsú, J.; L.F. de Paula and G.T. LIMA (Org.). Macroeconomia Moderna: Keynes e a economia contemporânea. Editora Campus. Rio de Janeiro.

BERNAT, G.A. and T.G. JOHNSON (1991). "Distributional effects of household linkages", American Journal of Agricultural Economics 73 (2), pp. 326-333.

CARDIM DE CARVALHO, F.J.; F.E. PIRES DE SOUZA, J. SICSU, L.F. RODRIGUES DE PAULA and R. STUDART (2001). Economia Monetária e Financeira: Teoria e Política. Editora Campus. Rio de Janeiro.

CHICK, V. (1994). "A evolução do sistema bancário e a teoria da poupança, do investimento e dos juros", Ensaios FEE, Porto Alegre 15, pp. 09-23.

DOW, S.C. (1992). "The regional financial sector: a Scottish case study", Regional Studies 26 (7), pp. 619-631.

FRAY, L. (1961). Desenvolvimento econômico e estrutura do mercado financeiro. Editora Zahar, Rio de Janeiro.

GUILHOTO, J.J.M. and U.A. SESSO FILHO (2005). "Análise da estrutura produtiva da Amazônia Brazileira", Amazônia: Ciência e Desenvolvimento 1 (1), pp. 07-33.

GURLEY, J.G. and E.S. SHAW (1960). Money in a theory of finance. Washington: Brookings Institution. HIRSCHMAN, A.O. (1961). La estrategia del desarrollo económico. México, Fondo de Cultura Económica. LEONTIEF, W. (1966). Input-output economics. New York, Oxford University Press.

LEONTIEF, W. (1970). "Environmental repercussion and the economic structure: an input-output approach", Review of economics and statistics 52, pp. 262-271.

MANKIW, G.N. (1992). Macroeconomia. São Paulo, LTC.

MIYAZAWA, K. (1966). "Internal and external matrix multipliers in the input-output model", Hitotsubashi, Journal of Economics 1 (7), pp. 38-55.

PYATT, G. and J.J. ROUND (1979). "Accounting and fixed price multipliers in Social Accounting Matrix framework", The Economic Journal 68 (5), pp. 1175-1180.

RASMUSSEN, P.N. (1957). Studies in Inter-sectoral Relations. North-Holland, Amsterdam.

RASMUSSEN, P.N. (1963). Relaciones Intersectoriales.Aguilar, Madrid.

SANTANA, A.C. de (2004). "A construção e aplicação da matriz de contabilidade social à economia da Amazônia". In: Santos, M.L. dos and W.C. Vieira (Eds.), Métodos quantitativos em economia. Viçosa, Universidade Federal de Viçosa.

SCITOVSKY, T. (1969). "Dois conceitos de economias externas". In: Agarwala, A.N. and S.P. SINGH, A economia do subdesenvolvimento. Editora Forense, Rio de Janeiro.

STONE, R. (1985). "The disaggregation of the household sector in national accounts". In: Pyatt, G. and J.I. ROUND (Eds.), Social accounting matrices: a basic for planning. Washington, D.C., The World Bank. 